\title{
> Gjesteskribent
}

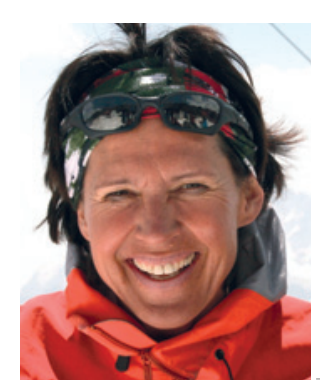

\section{Urealistiske forventninger - bidrar de til uførhet?}

\author{
I diskusjon rundt økningen i antall \\ uføre ser vi stadig at rasjonelle \\ tiltak foreslås som virkemidler, \\ som for eksempel endret sykmel- \\ dingspraksis, effektiviserings- \\ tiltak i sykehus og strengere rap- \\ porteringsrutiner for leger mot \\ NAV. Slike løsninger er etter mitt \\ syn mangelfulle. Helse dreier seg \\ ikke bare om diagnoser, fysiske \\ skader og kroniske lidelser, det er \\ også reaksjoner på det som har \\ skjedd, og de leges ikke på polikli- \\ nikkene eller på legekontoret.
}

Jeg har tidligere hatt en kreftdiagnose, og har nå leddgikt, osteoporose og artrose. Mine betraktninger bygger på egne erfaringer fra innleggelse i sykehus, opphold i rehabiliteringsinstitusjoner, erfaringer med NAV og den offentlige debatten. Jeg er i dag $60 \%$ ufør.

Mange av oss har en sterk yrkesidentitet. For de aller fleste har det å bli langtidssyk og uføretrygdet stor innvirkning på egenverd og selvtillit. I arbeidslivet materialiseres, forvaltes og utvikles kunnskap og erfaring. Personlige egenskaper og ferdigheter brynes og slipes, fellesskap utvikles og nettverk skapes. Ved langtidsfravær og uførhet reduseres, eller i verste fall opphører, slike sosiale strukturer. Når vi blir syke, raser noen ganger selve grunnmuren sammen. Dessuten er vår identitet knyttet til kroppen, til gleden ved å være i bevegelse, gjøre praktiske ting og delta i sosialt samvær. Men vi mennesker er mer enn det kroppen presterer. Alvorlig sykdom bringer med seg følelser som sorg, tap, fortvilelse, redsel og usikkerhet. Diagnosene river opp sår som ikke lar seg bandasjere eller medisinere. Livet blir for mange syke et utrygt og usikkert prosjekt og må realitetsbehandles på nytt. Helse er ikke bare diagnoser, fysiske skader eller kroniske lidelser. Helse er også hvordan psykiske reaksjoner møtes og håndteres.

Det er ikke noe i veien med den jobben sykehusene utfører. Innenfor strenge tidsrammer behandles og leges mange av sykdommene. Undersøkelsene blir gjort smidig og effektivt, det gipses og sys, blodprøver blir tatt, medisiner og resepter gitt. Det som skal gjøres, blir gjort, og jeg er dypt imponert over den profesjonaliteten jeg selv har møtt. Men etter at uførhetsdiagnosen min var et faktum, var jeg fullstendig uforberedt på det som ventet meg da døra til sykehuset lukket seg bak meg. Der ute møtte jeg noe som egentlig var mye verre og som har tatt lang tid å lege - psykisk smerte, krisefølelse og fortvilelse - reaksjonene på sykdommen. Selve identiteten ble rystet av diagnosen. Hvem var jeg nå?

Ikke alle er like heldig som meg, som har en lege som ringer for å spørre hvordan jeg har det og hva jeg trenger. På venteværelsene rundt forbi er tiden ofte for knapp for hver enkelt. Det er ikke tid til fortvilelse, skam, bitterhet, tap og redsel. Vi tar den med oss fra legekontoret til poliklinikken, til rehabiliteringsinstitusjoner og til NAV.

Som om ikke dette var nok forventes det av oss i dag at vi skal framstå som yngre, sterkere, sunnere og penere enn før. Kravet om vellykkethet på det ytre plan moser selvtilliten, og utmattelse og utbrenthet er like om hjørnet for mange av oss. Det resulterer ikke nødvendigvis i tunge psykiske lidelser, men den evige utilstrekkelighetsfølelsen gjør sitt til at hverdagen, med familie og jobb og de krav som stilles, blir for tung å bære, og den lar seg ikke helbrede med gips, bandasjer og sykehusinnleggelse. Den lar seg heller ikke enkelt diagnostisere og lar seg ikke lege i løpet av en tjue minutters konsultasjon hos fastlegen.

Det å finne nytt fotfeste i tilværelsen er en krevende oppgave. Igjen - jeg er heldig som har en coach som har veiledet meg gjennom denne tiden, hjulpet meg med å tømme en kontainer med skam og redsel, og som har lært meg hvordan jeg kan integrere sykdommen i livet mitt. Men jeg ser også at jeg i mange år har hatt urealistiske forventninger til hvor løsningene finnes.

Psykisk helse er undervurdert i uføredebatten. Urealistiske forventninger til at sykehus, fastlege og NAV skal løse dette i løpet av den tilmålte tiden lar seg ikke innfri. Fastlegen i en presset hverdag kan ikke forventes å klare å løse dette alene. Et samarbeid på tvers av profesjoner må til.

For pasienten finnes det løsninger. Det er mulig å finne mening i det meningsløse, å forsone seg med fortiden, få tillit til framtiden og bygge ny identitet, selv med diagnoser i bagasjen. Men uførediskusjonen må ikke bare dreie seg om sykmeldingspraksis og flere krav til sykehus og fastleger. Det går an å bygge en ny grunnmur i livet, selv etter at sykdom inntrer. Men noen må bære lecastein, andre må blande mørtel og noen må hjelpe deg med å lage plantegningen.

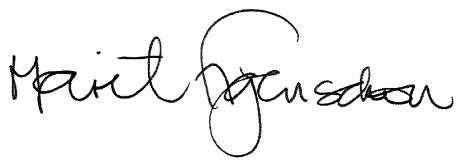

